\title{
Analisis Fenomena Budaya Foto Pre-Wedding Di Masyarakat: Studi Takhrij dan Syarah Hadis
}

\author{
Elsa Martina Rosa \\ Jurusan Ilmu Al-Qur'an dan Tafsir, Fakultas Ushuluddin \\ UIN Sunan Gunung Djati Bandung, Indonesia \\ elsamartinarosa290301@gmail.com
}

\begin{abstract}
This study aims to discuss the hadith syarah about seclusion regarding the phenomenon of the rise of pre-wedding culture in society. This study uses a qualitative approach that emphasizes literature review through the takhrij and syarah hadith methods. The results of this study found that the quality status of the hadith about seclusion is authentic. This hadith is judged authentic because all narrators are dzabit and fair (tsiqot) and because it is authentic and valid, this hadith is considered maqbul (accepted) so that it can be practiced. The conclusion of this study is that pre-wedding that is rampant in society contains elements of seclusion. Since the time of the Prophet, seclusion has been forbidden because it invites heinous acts. Therefore, the law of pre-wedding is haram. Except if there are no elements prohibited by the Shari'a and the intention is only to make it easier for the invited guests to recognize the bride and groom.
\end{abstract}

Keywords: Pre-wedding; Public; Seclusion

\begin{abstract}
Abstrak
Penelitian ini bertujuan untuk membahas syarah hadis tentang khalwat berkenaan dengan fenomena maraknya budaya prewedding di masyarakat. Penelitian ini menggunakan pendekatan kualitatif yang ditekankan pada kajian studi pustaka melalui metode takhrij dan syarah hadis. Hasil penelitian ini menemukan bahwa status kualitas hadis tentang khalwat yaitu shahih. Hadis ini dihukumi shahih karena semua perawi dzabit dan adil (tsiqot) dan karena shahih sanad dan juga matan maka hadits ini dihukumi maqbul (diterima) sehingga bisa diamalkan. Kesimpulan dari penelitian ini adalah prewedding yang marak di masyarakat mengandung unsur khalwat. Sejak zaman Nabi Saw khalwat dilarang karena mengundang perbuatan keji. Maka dari itu hukum dari prewedding adalah haram. Kecuali apabila tidak ada unsur yang dilarang oleh syariat dan niat hanya untuk memudahkan para tamu undangan mengenali kedua mempelai.
\end{abstract}


Jurnal Riset Agama, Volume 1, Nomor 1 (April 2021): 223-232

Elsa Martina Rosa/ Analisis Fenomena Budaya Foto Pre-Wedding Di

Masyarakat: Studi Takhrij dan Syarah Hadis

Kata kunci: Khalwat; Masyarakat; Prewedding

\section{Pendahuluan}

Foto prewedding berkembang pesat di China pada tahun 90-an setelah terbukanya sistem ekonomi di China. Di waktu yang bersamaan di Asia Timur sedang ramai dengan sinetron yang bernuansa percintaan. Sehingga banyak iklan yang dibuat untuk mempromosikan sinetron dengan menampilkan foto mesra pasangan (Irfan Helmi, 2016). Dari sanalah bermula maraknya foto mesra hingga banyak yang menggunakannya untuk foto prewedding. Fenomena foto prewedding menjadi hal yang lazim yang sering kita temui dan sudah menjadi gaya hidup sejak tahun 2000-an. Foto prewedding adalah bagian dari seni visual budaya popular (Nelly, 2018). Foto prewedding merupakan salah satu budaya Barat yang sekarang mulai banyak diikuti oleh masyarakat Indonesia. Foto prewedding biasanya terdapat dalam undangan pernikahan dan banyak juga yang menggunakannya untuk pajangan di pernikahannya. Fungsi dari surat undangan adalah untuk memberikan informasi kepada khalayak umum mengenai hajat keluarga pengantin untuk mengadakan acara walimah pernikahan. Perkembangan zaman akan baik jika sesuai dengan syariat agama. Tetapi apabila berlawanan dengan syariat agama maka tidak dapat diterima dengan mudah. Termasuk fenomena foto prewedding yang biasanya mengandung perilaku yang bertentangan dengan syariat Islam. Di antaranya yaitu ikhtilat, kasyful aurat, tabarruj, bersentuhan dengan lawan jenis dan mengandung unsur khalwat sehingga menjadi perhatian serius dari para tokoh agama juga menimbulkan pro dan kontra di masyarakat (Irfan Helmi, 2016). Oleh karena itu, melihat dari fenomena prewedding tersebut penulis tertarik untuk meneliti dan mengetahui lebih dalam pandangan tentang prewedding dan solusi terbaik selain dari dilakukan prewedding dengan landasan hadis menggunakan teori ilmu hadis dengan dilengkapi syarah.

Beberapa penulis telah melakukan penelitian mengenai fenomena prewedding. Di antaranya yaitu Hidayat, Syarif (2018), "Foto Prewedding dalam Perspektif Ulama Palangka Raya," Jurnal El-Maslahah. Penelitian ini menggunakan metode deskriptif kualitatif penulis mencoba memahami suatu kasus atau tradisi dan korelasi terhadap foto prewedding. Penelitian ini bertujuan untuk mengetahui motivasi kedua pasangan tersebut mengatur foto mereka dalam undangan pesta pernikahan dan pendapat ulama di Palangka Raya tentang foto pre-wedding dalam undangan pesta pernikahan. Para ulama pada umumnya lebih menyoroti pose dalam foto prewedding yang dilakukan oleh model yang belum memiliki status yang sah sebagai suami istri. Hal ini mengingat model foto prewedding yaitu calon 
Jurnal Riset Agama, Volume 1, Nomor 1 (April 2021): 223-232

Elsa Martina Rosa/ Analisis Fenomena Budaya Foto Pre-Wedding Di

Masyarakat: Studi Takhrij dan Syarah Hadis

mempelai belum memiliki status hukum sebagai suami istri yang sah dalam Islam. Dan para ulama bersepakat bahwa foto prewedding yang menampakan pakaian yang tidak menutup aurat adalah dilarang sebagaimana yang dijelaskan dalam QS. An-Nuur Ayat: 31. Selanjutnya keadaan lain yang menjadi kesepakatan para ulama dengan adanya foto prewedding adalah dalam hal berdandan atau bersolek. Karena kebanyakan orang selalu ingin terlihat cantik dan menarik pada saat difoto. Islam tidak membenarkan bagi umatnya untuk berlebih-lebihan dalam berias saat keluar rumah, sebagaimana firman Allah dalam QS. al-Ahzab Ayat 33. Dan yang perlu diperhatikan juga tujuan dibolehkannya foto prewedding bukan untuk menyombongkan diri, melainkan hanya sebatas untuk memudahkan orang mengenal identitas para mempelai. Kesimpulannya foto prewedding yang dilakukan setelah akad adalah boleh untuk dilakukan, sepanjang pose yang ditunjukan tidak mengarah kepada pornografi dan mengandung unsur membuka aurat, tabarruj, dan dalam tujuan untuk menyombongkan diri atau tujuan lain yang dilarang dalam Islam. Sedangkan dalam keadaan apabila model foto prewedding belum akad, maka foto prewedding ini adalah haram untuk dilakukan. Hukum ini sesuai dengan pendapat mayoritas ulama Palangka Raya yang menjadi subjek penelitian. Sebagaimana dengan melihat pertimbangan aspek manfaat dan mudharat yang ditimbulkan dari adanya foto prewedding (Hidayat, 2018). Helmi, Irfan (2016), “Budaya Foto Prewedding dalam Pandangan Hukum Islam." Penelitian ini menggunakan jenis penelitian kualitatif. Majelis Ulama Indonesia (MUI) Sumatra Utara memberikan fatwa bahwa prewedding hukumnya haram. Ketua MUI K.H Chalil Ridwan juga berpendapat jika belum menikah, maka perilakuperilaku yang biasanya dilakukan suami istri itu haram dilakukan. Terlebih lagi beliau berpendapat bahwa yang menjadi pokok masalah dalam foto pemotretan prewedding yaitu terlaksananya perilaku-perilaku muda-mudi yang belum menikah, namun dalam adegan itu menggambarkan seakanakan mereka telah menikah. Seperti adanya ikhtilat, khalwat dan kasyful aurat. Kesimpulannya dalam hukum Islam, mereka yang belum ada ikatan tali pernikahan, haram hukumnya bermesra-mesraan, berdua-duaan layaknya suami istri. Terlebih pakaian yang membuka aurat dan tidak adanya hijab semakin menambah keharaman pada pemotretan prewedding tersebut (Irfan Helmi, 2016). Dwi Wibowo, Agus (2019), “Hukum Foto Prewedding dalam Perspektif Kyai Pondok Pesantren di Kabupaten Blitar." Metode penelitian yang digunakan peneliti adalah metode kualitatif dan jenis penelitian lapangan (field research). Fotografi diperbolehkan dalam Islam akan tetapi, harus diperhatikan juga objek dari gambar tersebut apakah sesuai dengan syariat Islam atau tidak. Objek gambar mempunyai pengaruh untuk menetapkan hukum, mengenai haram dan halalnya. Adapun mengenai hukum halalnya seperti halnya seseorang yang 
Jurnal Riset Agama, Volume 1, Nomor 1 (April 2021): 223-232

Elsa Martina Rosa/ Analisis Fenomena Budaya Foto Pre-Wedding Di

Masyarakat: Studi Takhrij dan Syarah Hadis

mengambil gambar dengan objek sesuai syariat Islam. Adapun yang bersifat haram yaitu mengambil gambar dengan pakaian telanjang dan menampakan aurat wanita yang dapat membangkitkan syahwat seseorang. Tidak diragukan lagi bahwa semua itu hukumnya haram, baik mengambil gambar, melihat gambar, maupun menyebarluaskan gambar tersebut. Kesimpulannya, menurut perspektif kyai pondok pesantren di Kabupaten Blitar. Mengenai hukum foto prewedding yang terjadi di Kabupaten Blitar adalah haram, karena melanggar syariat Islam, seperti ikhtilat, khalwat, tabaruj, dan membuka aurat. Apalagi foto prewedding dilakukan sebelum adanya akad nikah. Hukum foto prewedding dalam perspektif hukum Islam adalah haram, karena mengandung unsur ikhtilat, khalwat, tabaruj, dan membuka aurat (Wibowo, 2019).

Penelitian-penelitian terdahulu sangat bermanfaat bagi penyusunan kerangka berpikir penelitian ini. Dalam penelitian ini penulis akan lebih mendalami mengenai salah satu unsur yang terdapat dalam prewedding yaitu khalwat. Khalwat merupakan perilaku berdua-duaan antara laki-laki dan perempuan yang belum ada ikatan pernikahan di tempat yang sepi tanpa di damping mahrom dari pihak laki-laki maupun pihak perempuan (Zaini, n.d.). Khalwat di zaman modern ini bentuknya sangat bervariasi untuk itu diperlukan kajian lebih mendalam tentang hal ini. Dan akan dikaji pula takhrij dan syarah hadis yang menerangkan khalwat. Hadis merupakan sumber ajaran Islam setelah al-Quran dan memiliki kedudukan yang sangat penting. Hadis merupakan semua hal yang berasal dari Nabi Muhammad Saw (Darmalaksana \& Qomaruzzaman, 2020). Takhrij menurut Mahmud al-Thahhan adalah penelusuran tempat hadis berdasarkan sumber-sumbernya yang asli dalam menyebutkan hadis dengan sanadnya, selanjutnya dikaji kembali kualitas hadisnya. Adapun Syarah hadis yaitu penjelasan yang berkaitan dengan hadis, yaitu upaya untuk menafsirkan makna yang terkandung di dalam teks hadis (Darmalaksana, 2020c).

Berdasarkan dari pemaparan di atas, penulis berupaya menyusun formula penelitian yaitu rumusan masalah penelitian, pertanyaan utama penelitian dan tujuan penelitian (Darmalaksana, 2020a). Rumusan masalah penelitian ini adalah terdapat syarah hadis berkenaan dengan fenomena maraknya prewedding di masyarakat. Adapun pertanyaan penelitian ini yaitu bagaimana hadis yang berkaitan dengan fenomena prewedding. Dan pertanyaan terperincinya yaitu bagaimana teks hadis tentang khalwat, bagaimana kualitas hadis tentang khalwat dan bagaimana syarah hadis tentang khalwat berkenaan dengan fenomena maraknya budaya prewedding di masyarakat. Tujuan penelitian ini yaitu membahas syarah hadis tentang khalwat berkenaan dengan fenomena maraknya budaya prewedding di masyarakat. Dengan adanya penelitian ini diharapkan dapat memberikan 
Jurnal Riset Agama, Volume 1, Nomor 1 (April 2021): 223-232

Elsa Martina Rosa/ Analisis Fenomena Budaya Foto Pre-Wedding Di

Masyarakat: Studi Takhrij dan Syarah Hadis

pandangan kepada masyarakat tentang hukum prewedding dan solusi terbaik selain dari prewedding.

\section{Metode Penelitian}

Penelitian ini tidak terjun langsung ke lapangan atau dengan kata lain menggunakan pendekatan kualitatif melalui studi pustaka (Darmalaksana, 2020b). Metode dalam penelitian ini menggunakan metode takhrij dan syarah hadis (Darmalaksana, 2020d). Dan interpretasi yang digunakan yaitu analisis kontemporer (Darmalaksana, 2020c).

\section{Hasil dan Pembahasan}

Hasil dari penelitian dan pembahasan sebagai berikut.

\section{Teks Hadis tentang Khalwat}

Terdapat tiga hadis yang ditemukan setelah melakukan pencarian hadis tentang khalwat melalui aplikasi Ensiklopedia Hadis 9 Imam. Di antaranya yaitu hadis riwayat Ahmad No. 1833, hadis riwayat Bukhari No. 2784 dan hadis riwayat Muslim No. 2391. Akan tetapi hanya satu hadis yang akan menjadi pembahasan utama penelitian ini yaitu hadis riwayat Ahmad No. 1833. Adapun redaksi hadisnya sebagai berikut:

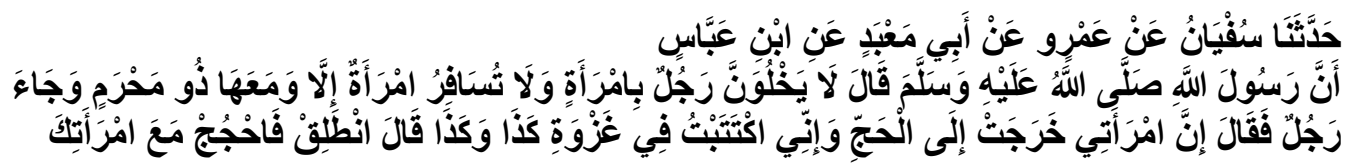

Telah menceritakan kepada kami Sufyan dari 'Amru dari Abu Ma'bad dari Ibnu Abbas; bahwa Rasulullah bersabda, "Janganlah seorang lakilaki berduaan dengan seorang wanita (yang bukan mahramnya), dan janganlah seorang wanita bepergian kecuali bersama mahramnya." seorang laki-laki datang dan bertanya, "Sesungguhnya istriku hendak keluar untuk berhaji, sedang aku ikut serta dalam perang ini dan itu." Maka Rasulullah bersabda, "Pulanglah dan temanilah istrimu berhaji" (HR. Ahmad 1833).

\section{Daftar Rawi dan Sanad Hadis Khalwat}

Daftar rawi dan sanad hadis riwayat Ahmad No. 1833 sebagai berikut:

Tabel 1. Daftar Rawi dan Sanad

\begin{tabular}{|c|c|c|c|c|c|c|c|c|}
\hline \multirow[t]{2}{*}{ No. } & \multirow{2}{*}{$\begin{array}{l}\text { Rawi } \\
\text { Sanad }\end{array}$} & \multicolumn{2}{|c|}{$\begin{array}{l}\text { Lahir/ } \\
\text { Wafat }\end{array}$} & \multirow{2}{*}{ Negeri } & \multirow{2}{*}{ Kuniyah } & \multicolumn{2}{|r|}{$\begin{array}{c}\text { Komentar } \\
\text { Ulama }\end{array}$} & \multirow{2}{*}{ Kalangan } \\
\hline & & $\mathrm{L}$ & $\mathrm{W}$ & & & - & + & \\
\hline 1 & $\begin{array}{l}\text { Abdullah } \\
\text { bin } \\
\text { Abbas }\end{array}$ & $3 \mathrm{H}$ & $\begin{array}{l}68 \\
\mathrm{H}\end{array}$ & $\begin{array}{l}\text { Madinah } \\
\text { dan Tha'if }\end{array}$ & Ibnu Abbas & & Adil & Sahabat \\
\hline
\end{tabular}


Jurnal Riset Agama, Volume 1, Nomor 1 (April 2021): 223-232

Elsa Martina Rosa/ Analisis Fenomena Budaya Foto Pre-Wedding Di

Masyarakat: Studi Takhrij dan Syarah Hadis

\begin{tabular}{|c|c|c|c|c|c|c|c|}
\hline 2 & $\begin{array}{l}\text { Nafidz } \\
\text { Abu } \\
\text { Ma'bad } \\
\text { Maula } \\
\text { Ibnu } \\
\text { Abbas al- } \\
\text { Makky }\end{array}$ & & $\begin{array}{c}104 \\
\mathrm{H}\end{array}$ & Hijaz & Abu Ma'bad & $\begin{array}{l}\text { Tsiqot; Tsiqot; } \\
\text { Tsiqot; Tsiqot; } \\
\text { Tsiqot; Tsiqot } \\
\text { hasanul hadis; } \\
\text { Tsiqot } \\
\text { Disebutkan } \\
\text { dalam ats- } \\
\text { tsiqot, min } \\
\text { ashdaqi } \\
\text { mawla Ibnu } \\
\text { Abbas }\end{array}$ & $\begin{array}{l}\text { Thabaqat } \\
\text { keempat, } \\
\text { wustha } \\
\text { tabi'in }\end{array}$ \\
\hline 3 & $\begin{array}{l}\text { Abu } \\
\text { Muham } \\
\text { mad } \\
\text { 'Amr bin } \\
\text { Dinar al- } \\
\text { Makki al- } \\
\text { Jumahiy }\end{array}$ & $\begin{array}{l}46 \\
\mathrm{H}\end{array}$ & $\begin{array}{c}126 \\
\mathrm{H}\end{array}$ & & $\begin{array}{l}\text { Abu } \\
\text { Muhammad }\end{array}$ & $\begin{array}{l}\text { Tsiqot; Tsiqot } \\
\text { tsiqot; Tsiqot } \\
\text { tsabt; Hufadz } \\
\text { dan } \\
\text { Ziyadahnya } \\
\text { diterima; } \\
\text { Tsiqot tsabt } \\
\text { katsirul hadis; } \\
\text { Perawi yang } \\
\text { banyak } \\
\text { dijadikan } \\
\text { sandaran } \\
\text { dalam hadis }\end{array}$ & $\begin{array}{l}\text { Thabaqat } \\
\text { keempat, } \\
\text { Wustha } \\
\text { Tabi'in }\end{array}$ \\
\hline 4 & $\begin{array}{l}\text { Sufyan } \\
\text { bin } \\
\text { Uyainah } \\
\text { bin } \\
\text { Maymun }\end{array}$ & $\begin{array}{c}107 \\
\mathrm{H}\end{array}$ & $\begin{array}{c}198 \\
\mathrm{H}\end{array}$ & $\begin{array}{l}\text { Mekkah } \\
\text { Kuffah }\end{array}$ & & $\begin{array}{l}\text { Tsiqot hafidz } \\
\text { faqih Imam } \\
\text { Hujjah } \\
\text { kecuali di } \\
\text { akhir } \\
\text { umurnya; } \\
\text { Tsiqot; Hafidz } \\
\text { tsiqot tsabt; } \\
\text { Tsiqot tsabt } \\
\text { dalam hadis; } \\
\text { Diterima } \\
\text { tadlis-nya; } \\
\text { Hafidz tsiqot }\end{array}$ & $\begin{array}{l}\text { Thabaqat } \\
\text { kedelapa, } \\
\text { Wustha } \\
\text { Tabi'it } \\
\text { Tabi'in }\end{array}$ \\
\hline 5 & $\begin{array}{l}\text { Abu } \\
\text { Abdullah } \\
\text { Ahmad } \\
\text { bin } \\
\text { Muham } \\
\text { mad bin } \\
\text { Hambal }\end{array}$ & $\begin{array}{c}163 \\
\mathrm{H}\end{array}$ & $\begin{array}{c}240 \\
\mathrm{H}\end{array}$ & $\begin{array}{l}\text { Merv } \\
\text { Baghdad }\end{array}$ & $\begin{array}{l}\text { Abu } \\
\text { Abdullah }\end{array}$ & $\begin{array}{l}\text { Imam dan } \\
\text { seorang } \\
\text { hujjah; Salah } \\
\text { satu imam; } \\
\text { Tsiqoh hafidz } \\
\text { faqih hujjah; } \\
\text { Tsiqoh } \\
\text { Ma'mun } \\
\text { salah satu } \\
\text { imam; } \\
\text { Imam; Aku } \\
\text { tidak pernah } \\
\text { melihat } \\
\text { orang yang } \\
\text { paling 'alim } \\
\text { dan wara' } \\
\text { selain } \\
\text { dirinya; }\end{array}$ & $\begin{array}{l}\text { Mudawwin } \\
\text { Thabaqat } \\
\text { kesepuluh, } \\
\text { Kibaru al- } \\
\text { Akhd an } \\
\text { Tabi'it } \\
\text { Tabi'in }\end{array}$ \\
\hline
\end{tabular}


Jurnal Riset Agama, Volume 1, Nomor 1 (April 2021): 223-232

Elsa Martina Rosa/ Analisis Fenomena Budaya Foto Pre-Wedding Di

Masyarakat: Studi Takhrij dan Syarah Hadis

\begin{tabular}{|l|l|l|l|l|l|l|l|}
\hline & & & & & $\begin{array}{l}\text { A'lamid Din; } \\
\text { Tsiqot tsabt }\end{array}$ & \\
\hline
\end{tabular}

Table 1 merupakan daftar rawi dan sanad dari hadis di atas yang diriwayatkan oleh Imam Ahmad No. 1833 tentang khalwat. Hadis ini diriwayatkan oleh 5 (lima) orang rawi berawal dari seorang sahabat dan diakhiri dengan Mudawwin yaitu Abu Abdullah Ahmad bin Muhammad bin Hambal atau sering disebut dengan Imam Ahmad. Dari lima rawi di atas, hanya ada satu rawi yang tidak diketahui tahun lahirnya yaitu Nafidz Abu Ma'bad Maula Ibnu Abbas al-Makky. Adapun yang dimaksud dengan diterima tadlisnya dalam kolom Sufyan bin Uyainah bin Maymun yaitu seseorang menggugurkan rawi yang di atasnya (gurunya) dalam sanad dan menyandarkan hadis yang diriwayatkan olehnya kepada guru di atas rawi yang digugurkan dan dia sendiri dengan rawi yang digugurkan tadi memang sudah bertemu. Memang tadlis itu ada yang diterima dan ada yang ditolak. Tadlis yang diterima itu adalah tadlis yang dilakukan oleh perawi yang tsiqat, sedangkan yang tidak diterima itu yang dilakukan oleh rawi yang dhaif. Statusnya diperinci, apabila menggunakan lafadz yang menunjukkan benar-benar telah mendengar suatu hadis dari gurunya seperti sami'tu dan lainnya maka diterima. Tetapi apabila sebaliknya yaitu menggunakan lafadz sighat tamrid seperti 'an atau qala dan semacamnya, maka tidak diterima. Rawi pertama dari hadis ini adalah Abdullah bin Abbas. Sedangkan sanad pertama dari hadis ini adalah Abu Abdullah Ahmad bin Muhammad bin Hambal. Berdasarkan ilmu hadis rawi pertama merupakan sanad terakhir sedangkan rawi terakhir merupakan sanad pertama (Darmalaksana, 2021b).

\section{Kualitas Hadis tentang Khalwat}

Syarat hadis shahih yaitu apabila rawi adil dan dhabit, sanad bersambung (tidak terputus), matan hadis tidak ada syadz dan tidak cacat ('illat) (Darmalaksana, 2018, 2020d). Dilihat dari tabel rawi dan matan hadis di atas dapat diambil kesimpulan bahwa hadis ini dihukumi shahih, karena semua perawinya dzabit dan adil (tsiqat). Selain itu, hadis di atas dihukumi shahih karena perawinya semua kemungkinan muttasil (tersambung) jika dilihat dari tahun lahir dan wafat serta thabaqat para rawi. Walaupun dari tabel di atas yang tidak diketahui tahun lahirnya hanya Nafidz Abu Ma'bad Maula Ibnu Abbas al-Makky, tetapi kemungkinan besar beliau bertemu dengan Abu Muhammad 'Amr bin Dinar al-Makki al-Jumahiy. Dilihat dari beliau wafat dan dari lahirnya Abu Muhammad 'Amr bin Dinar al-Makki alJumahiy. Jadi dapat disimpulkan keduanya masih bersambung. Dari sudut matan hadis maka tidak ditemukan hadis-hadis shahih yang memiliki matan yang bertentangan dengan matan hadis tersebut sehingga matan 
Jurnal Riset Agama, Volume 1, Nomor 1 (April 2021): 223-232

Elsa Martina Rosa/ Analisis Fenomena Budaya Foto Pre-Wedding Di

Masyarakat: Studi Takhrij dan Syarah Hadis

hadis tersebut tidak dihukumi syadz. Dengan kata lain, matan hadis tersebut juga berkualitas shahih.

\section{Syarah Hadis tentang Khalwat}

Syarah hadis merupakan penjelasan keshahihan, kecacatan sanad dan matan hadis juga makna-maknanya disertai dengan hikmah dan hukumnya. Syarah hadis meliputi penjelasan redaksi hadis untuk diperoleh pemahaman bagi pengalan hadis (Darmalaksana, 2020c). Hadits ini memiliki derajat shahih li dzatihi. Hadits ini memiliki banyak penguat dari beragam jalur (sanad) seperti HR. at-Tirmidzi No. 2165, HR. an-Nasai No. 8625, HR. Abu Ya'la No. 194 dan 195, HR. Muslim No. 1270 dan sebagainya. Sehingga karena shahih sanadnya dan juga banyaknya jalur atau sanad maka hadits ini dihukumi maqbul (diterima) sehingga bisa diamalkan.

Syarah hadits (fighul hadits) atau penjelasan dari hadits tersebut adalah haram hukumnya khalwat (berduaan) antara lawan jenis. Hal ini dapat kita fahami daripada shigat nahyi (larangan) yang ada pada hadits tersebut sedangkan kaidah ushul fiqh menyatakan:

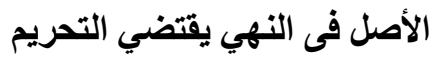

Artinya: "Hukum asal dalam larangan adalah haram."

Kaidah ini atau yang semakna dengannya dapat kita temukan dalam kitab Waraqat, Ghayatul Wushul, Alluma, Jam'ul Jawani dan yang lainnya.

Larangan khalwat (berduaan) antara lawan jenis yang ada pada hadits tersebut tentunya berlaku sejak zaman Rasulullah Saw hingga masa sekarang. Sejak jauh-jauh hari, Rasulullah Saw melarang kita untuk melakukan khalwat atau berdua-duaan dengan lawan jenis karena syetan akan menjadi orang ketiga di antara keduanya. Syetan akan membisikan hal-hal maksiat kepada mereka berdua yang nantinya mereka berdua akan terjerumus ke dalam perbuatan yang tidak senonoh seperti zina. Hal ini tegas dikatakan oleh Syekh Muhammad Abdurrahman al-Mubarakfuri dalam kitabnya Tuhfatul Ahwadzi Syarah Sunan at-Tirmidzi. Semua jenis khalwat yang dikemas dengan beragam model dan trend masa kini, tentunya tetap dihukumi haram karena memiliki esensi yang sama, yaitu berduaan dengan lawan jenis. Oleh sebab itulah maka seorang perempuan menurut hadits ini dinyatakan haram melakukan perjalanan kecuali dengan ditemani oleh mahram (Zaini, n.d.).

Syekh Muhammad bin Salim bin Sa'id Babashil (Abdullah bin husain, n.d.) menjelaskan bahwa seburuk-buruk hal-hal yang diharamkan dan setegas-tegasnya hal yang dilarang adalah khalwat antara laki-laki dan 
Jurnal Riset Agama, Volume 1, Nomor 1 (April 2021): 223-232

Elsa Martina Rosa/ Analisis Fenomena Budaya Foto Pre-Wedding Di

Masyarakat: Studi Takhrij dan Syarah Hadis

perempuan dalam sebuah perkumpulan karena hal itu dapat menimbulkan kerusakan dan fitnah yang keji. Oleh karena itu, haram hukumnya melakukan foto prewedding antara kedua mempelai yang sama sekali belum melangsungkan akad pernikahan walaupun sudah menjadi adat kebiasaan atau bahkan tradisi dalam masyarakat kita. Hal ini karena adanya unsur khalwat atau ikhtilath (berduaan antara lawan jenis) yang bukan mahram pada prosesi foto prewedding tersebut. Foto prewedding tentunya dihukumi terlarang dari sisi ini. Yang mendapat dosa tentunya adalah tidak hanya kedua calon mempelai, namun juga fotografer karena turut berperan dalam proses pembuatan foto prewedding tersebut. Ketika ia berperan, maka ia menunjukkan sikap rela terhadap kemaksiatan, sedangkan rela terhadap kemaksiatan merupakan sebuah perbuatan maksiat juga yang haram hukumnya.

\section{Kesimpulan}

Pada pelaksanaan prewedding terdapat unsur-unsur yang diharamkan oleh syariat. Di antaranya khalwat, kasyful aurat, bersentuhan dengan lawan jenis, ikhtilat, dan tasyabbuh. Dan pada penelitian ini mengambil salah satu yang terkandung dalam prewedding yaitu khalwat. Larangan khalwat sudah ada sejak zaman Rasulullah Saw. Terdapat beberapa hadis yang menjelaskan tentang khalwat dan salah satunya yang diriwayatkan oleh Imam Ahmad No. 1833. Dilihat dari rawi dan matan, hadis ini dihukumi shahih karena semua perawinya dzabit dan adil (tsiqat). Dan status hadits ini memiliki derajat shahih li dzatihi. Hadits ini memiliki banyak penguat dari beragam jalur (sanad) seperti HR. at-Tirmidzi No. 2165, HR. an-Nasai No. 8625, HR. Abu Ya'la No. 194 dan 195, HR. Muslim No. 1270 dan sebagainya. Sehingga karena shahih sanadnya dan juga banyaknya jalur atau sanad maka hadits ini dihukumi maqbul (diterima) sehingga bisa diamalkan. Maka hukum prewedding dihukumi haram, tidak hanya bagi pasangannya yang mendapatkan dosa tapi juga orang-orang yang terlibat di dalamnya. Kecuali apabila tidak ada unsur yang dilarang oleh syariat dan niat hanya untuk memudahkan para tamu undangan mengenali kedua mempelai. Dan solusinya supaya diganti dengan foto pasca-wedding karena keduanya sudah halal menjadi pasangan suami istri. Penelitian ini diharapkan membawa banyak manfaat bagi masyarakat yang mengganggap bahwa prewedding menjadi tradisi yang diperbolehkan. Penelitian ini masih banyak kekurangan karena keterbatasan dan kekurangan peneliti dalam menguasai ilmu hadis. Sehingga diperlukan kembali penelitian lebih lanjut, terutama dari segi ilmu takhrij hadis dengan analisis sesuai isu kontemporer. Penelitian ini merekomendasikan supaya adanya kolaborasi antara peminat ilmu hadis dan ilmu figh untuk meneliti lebih lanjut mengenai solusi terbaik dari tidak dilakukannya prewedding. 
Jurnal Riset Agama, Volume 1, Nomor 1 (April 2021): 223-232

Elsa Martina Rosa/ Analisis Fenomena Budaya Foto Pre-Wedding Di

Masyarakat: Studi Takhrij dan Syarah Hadis

\section{Daftar Pustaka}

Abdullah bin husain, H. (n.d.). دمحم نب رهاط نب نبيح نب الله دبع بييحلا بولعاب مشاه نب hidayat, syarif. (2018). Foto Prewedding dalam Persfektif Ulama Palangka Raya. $8(1)$.

Irfan Helmi. (2016). Budaya Foto Prewedding dalam Pandangan Hukum Islam. Wibowo, A. D. (2019). Hukum Foto Prewedding dalam Perspektif Kyai Pondok Pesantren di Kabupaten Blitar. April.

Zaini, M. (n.d.). Khalwat dalam Islam (Kajian Fiqh Al-Hadis). Jurnal Kopertais Aceh, 45-63.

Darmalaksana, W. (2021). Pre-Print Kelas Menulis UIN Sunan Gunung Djati Bandung 2021. 19, 1-11.

Darmalaksana, W. (2020a). Formula Penelitian Pengalaman Kelas Menulis. Jurnal Kelas Menulis UIN Sunan Gunung Djati Bandung. http://digilib.uinsgd.ac.id/32620/

Darmalaksana, W. (2020b). Metode Penelitian Kualitatif Studi Pustaka dan Studi Lapangan. Pre-Print Digital Library UIN Sunan Gunung Djati Bandung.

Darmalaksana, W. (2020c). Penelitian Metode Syarah Hadis Pendekatan Kontemporer: Sebuah Panduan Skripsi, Tesis, dan Disertasi. Diroyah: Jurnal Studi Ilmu Hadis, 5.

Darmalaksana, W. (2020d). Prosiding Proses Bisnis Validitas Hadis untuk Perancangan Aplikasi Metode Tahrij. Jurnal Ushuluddin UIN Sunan Gunung Djati Bandung, 1, 1-7.

Darmalaksana, W. (2021b). Kosmetik Halal sebagai Lifestyle untuk Kesehatan: Studi Takhrij dan Syarah Hadis.

Rahman, A. (2017). Pengenalan Atas Takhrij Hadis. Riwayah: Jurnal Studi Hadis, 2(1), 146. https://doi.org/10.21043/riwayah.v2i1.1617

Saltanera. (2015). Ensiklopedia Hadis 9 Imam. In. Lembaga Ilmu dan Dakwah Publikasi Sarana Keagamaan, Lidwa Pusaka.

Wibowo, A. D. (2019). Hukum Foto Prewedding dalam Perspektif Kyai Pondok Pesantren di Kabupaten Blitar. April.

Zaini, M. (n.d.). Khalwat dalam Islam (Kajian Fiqh Al-Hadis). Jurnal Kopertais Aceh, 45-63. 